Mediscope

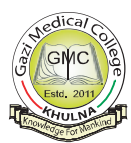

The Journal of GMC

\title{
ABO and Rh-D blood group distribution in a rural population of Bangladesh
}

\author{
RM Hira ${ }^{1}$, LK Dhali ${ }^{2}$, ND Dhali ${ }^{3}$, DH Akash ${ }^{4}$
}

\begin{abstract}
This is an observational cross-sectional study aiming to identify the distribution patterns of $A B O$ and Rh-D blood group in a rural population of Bagerhat District, Bangladesh in order to promote social awareness and safe blood transfusion among the population. After proper ethical consideration, a total of 164 people of a village in Bagerhat District were included in this study. They were selected irrespective of age and sex by systematic random sampling. ABO and Rh-D blood groups were determined by the antigen antibody agglutination test of slide method. The ABO group distribution, O (34.1\%), A (26.2\%), B (25.6\% and AB (14.0\%). Of the respondents, $105(64.0 \%)$ were male and 59 (36.0\%). The frequency of group O+ve comprised the highest (32.9\%) of the samples followed by group $A+v e, B+v e$ and $A B+v e$. The majority of the subjects were Rh-D positive (94.5\%). It is observed that Rh-D positive group is more common in subjects with $\mathrm{O}$ group whereas $\mathrm{Rh}-\mathrm{D}$ negative group is more common in $\mathrm{B}$ group. Most common blood group among this village population was O+ve which can safely be transfused to any other group. The study of blood grouping can generate database and create social awareness about self-blood grouping and safe blood transfusion among the population.
\end{abstract}

Keywords: ABO, Rh-D, blood group system, social awareness, Bangladesh

\section{Introduction}

Human body carries around 4-6 litres (8.5-12.5 pints) of blood. Blood is made up of red blood cells, white blood cells and platelets in liquid called plasma. Plasma is about $90 \%$ water, but also contains proteins, nutrients, hormones and waste products. Blood is made up of about $60 \%$ plasma and $40 \%$ blood cells. Blood groups are important hereditary characteristics of a person and are useful in population and genetic studies, in resolving medico-legal issues and more importantly in compatibility test in blood transfusion practice. Blood group has wider implication such as relation between genetic characteristics, susceptibility to particular diseases and exposure to various environmental factors. ${ }^{1}$ Blood group also associated with tissue grafts, hemolytic diseases of new born and certain other

1. RM Hira, MBBS, MPhill, Associate Professor of Anatomy, Kushtia Medical College, Kushtia

2. LK Dhali, Asstt. Surgeon, Gazi Medical College Hospital, Khulna

3. ND Dhali, Professor of Pcychology, Sarwar Khan College, Digholia, Khulna

4. DH Akash, Medical Student, Dhaka Medial College, Dhaka 
diseases like peptic ulcer, diabetes and malignancy.

Blood group is identified by antigens and antibodies present in the blood. Antigens and antibodies are human blood's natural defense against foreign substances. Antigens are protein molecules found on the surface of red blood cells, a series of glycoproteins. Development of these antigens are genetically controlled and they appear early in fetal life and remain unchanged till death. ${ }^{2}$ Antibodies are found in plasma. Antibodies recognize anything foreign in human body and alert immune system so that it can destroy it.

The kind of blood a person has is determined by the genes he or she inherits from the parents and is divided into different types, known as blood groups. There are many blood group systems on the basis of different blood group antigens. Of them the $A B O$ and Rhesus (Rh-D) antigens are recognized as the major clinically significant blood group antigens. ${ }^{3}$ The major $\mathrm{ABO}$ blood group system is divided into four blood types on the basis of presence or absence of $A$ and $B$ surface antigens. The blood groups are $A, B, O$ and $A B$. The frequency of four main $\mathrm{ABO}$ blood groups varies in the population throughout the world. ABO blood group system derives its importance from the fact that $A$ and $B$ are strongly antigenic and anti-A and anti-B naturally occurring antibodies present in the serum of persons lacking the corresponding antigen and these antibodies are capable of producing intravascular hemolysis in case of incompatible transfusion. ${ }^{4}$

In Rh-D system blood groups are Rh-D positive or Rh-D negative on the basis of presence or absence of Rh-D antigen on red blood cells surface. This means that a person can be one of eight blood groups: $A$ Rh-D positive $(A+v e), A$ Rh-D negative (A-ve), B Rh-D positive (B+ve), B Rh-D negative (B-ve), O Rh-D positive (O+ve), $O$ Rh-D negative (O-ve), AB Rh-D positive $(A B+v e)$ and $A B R h-D$ negative (AB-ve).
Receiving blood from the wrong $\mathrm{ABO}$ group could be life threatening because antibodies in a person with group $A$ blood will attack group $B$ antigens and vice versa. This will cause a severe reaction in the person receiving the blood. Red blood cells of O+ve group blood do not have any A or B antigen; it can safely be given to any other group. In most cases, O-ve blood can safely be given to anyone. However, this depends on specific antibodies and antigens being present in the blood.

Blood group and Rh-D system bear a very great importance and these are being determined before transfusion, chiefly in women of child bearing age. They are also important for studying the inheritance of genes to establish parentage in case of disputed paternity and in forensic science. ${ }^{5}$

To work out blood group, red cells of blood are mixed with different antibody solutions. If, for example, the solution contains anti-B antibodies and one has $\mathrm{B}$ antigens on blood cells, it will clump together. If the blood does not react to any of the anti-A or anti-B antibodies, it is blood group O. A series of tests with different types of antibody can be used to identify blood group, including groups other than the main $A B O$ and $R h-D$ groups. Though finding out the blood groups needs very easy and quick procedure, no one cares for knowing his/her blood group in country like Bangladesh. People go for this test only when blood transfusion is needed. It should be done as early as possible in life so that no problem arrives if blood transfusion needed in emergency and also after marriage due to Rh-D incompability. ${ }^{6}$

An extensive review of available literature has been revealed that there has been one study conducted on $A B O$ and Rh-D blood grouping among village people in Bangladesh. ${ }^{7}$ The present study was conducted to observe the distribution pattern of $A B O$ and Rh-D blood groups of common people in a area of Bangladesh to fill this lacunae. 
Materials and Method

This observational cross sectional study was conducted in a satellite camp for blood grouping of village people in the village named Moubhoge, Upozila- Fakirhat, District- Bagerhat, Bangladesh. People of the study area were announced previously informing that their blood grouping would be done with free of cost, also mentioning the time, date and place of testing their blood groups. A total of 165 samples were selected irrespective of age and sex by systematic random sampling during the period of $3 \mathrm{rd}$ and 4th July, 2013. The name, age, sex and $A B O$ and Rh-D blood groups of the samples were recorded.

The test was performed using rapid slide test technique for blood groups as described in a study. 8 Two areas were marked out on a glass slide labeled $A$ and $B$. Then one drop of corresponding anti-serum was added to the above areas. One drop of blood was added to each of the labeled area after aseptic washing, with $70 \%$ ethyl alcohol, of the left ring finger tip with the help of a sterile lancet. The cell and anti-serum mixture was mixed well. Test that did not show agglutination within two minutes were considered negatives. Agglutination of red blood cells in the presence of anti-serum was considered as positive test result.

The Rh-D grouping was also carried out using rapid slide test. For Rh-D system, human monoclonal Anti-Rh-D antibody was used. One drop of Anti-Rh-D reagent was put on the slide and one drop of blood was mixed. The agglutination reaction appeared and the test was read as positive test. Where there was no agglutination, the test was read as negative.

Data on the frequency of $A B O$ and $R h-D$ blood groups were reported descriptively in simple percentages.

\section{Results}

During the study period total 164 blood samples were collected. Of these 105 $(64.0 \%)$ were male and $59(36.0 \%)$ were female with male: female ratio 1.8:1.
Table 1. Distribution of $A B O$ and Rh blood groups of the study population, $(n=164)$

\begin{tabular}{lcc}
\hline Blood group & Number & Percentage \\
\hline A+ve & 41 & 25.0 \\
B+ve & 39 & 23.8 \\
AB+ve & 21 & 12.8 \\
O+ve & 54 & 32.9 \\
A-ve & 2 & 1.2 \\
B-ve & 3 & 1.8 \\
AB-ve & 2 & 1.2 \\
O-ve & 2 & 1.2 \\
\hline
\end{tabular}

Table 2. Frequency of Rh-D phenotype among the sample studied with respect to the ABO blood groups, $(n=164)$

\begin{tabular}{lrcc}
\hline Blood group & & Number & Percentage \\
\hline ABO & A & 43 & 26.2 \\
& B & 42 & 25.6 \\
& AB & 23 & 14.0 \\
& $O$ & 56 & 34.1 \\
\hline Rh-D & Positive & 155 & 94.5 \\
& Negative & 9 & 5.5 \\
\hline
\end{tabular}

Table 3. Distribution of gender profile of the study population, $(n=164)$

\begin{tabular}{lrr}
\hline $\begin{array}{l}\text { Blood group } \\
\text { (ABO \& Rh-D) }\end{array}$ & $\begin{array}{r}\text { Male } \\
\text { number (\%) }\end{array}$ & $\begin{array}{r}\text { Female } \\
\text { number (\%) }\end{array}$ \\
\hline A+ve & $27(16.5)$ & $14(8.5)$ \\
B+ve & $24(14.6)$ & $15(9.1)$ \\
AB+ve & $16(9.8)$ & $5(3.0)$ \\
O+ve & $32(19.5)$ & $22(13.4)$ \\
A-ve & $0(0)$ & $1(0.6)$ \\
B-ve & $2(1.2)$ & $1(0.6)$ \\
AB-ve & $2(1.2)$ & $0(0)$ \\
O-ve & $1(0.6)$ & $1(0.6)$ \\
\hline
\end{tabular}

Table 1 shows the distribution of various $\mathrm{ABO}$ and $\mathrm{Rh}$ phenotypes among the sample studied. The frequency of group $\mathrm{O}+\mathrm{ve}$ phenotype comprised the highest (32.9\%) of the samples followed by group $A+v e, B+v e$ and $A B+v e$. Table 2 shows the frequency of Rh-D phenotype among the sample studied with respect to the $A B O$ and $R h-D$ blood groups. The result of the present study depicts that majority of the subjects were 
Rh-D positive (94.5\%) whereas Rh-D negative was infrequent. It is observed that Rh-D positive group is more common in subjects with $O$ group whereas $R h-D$ negative group is more common in B group. Table 3 shows the gender profile of the study populations. It is observed that there was no $A$-ve in male group and no $A B$-ve in female group. $A+v e$ is more common than $B+v e$ in male group, but $B+v e$ is more common than $A+v e$ in female group.

\section{Discussion}

The present study has been carried out to determine the distribution pattern of $A B O$ and Rh-D blood groups in common people of a village area of Bagerhat District in Bangladesh. The collected data on blood group system can be used for development of donor database for collection of blood and create social awareness about self-blood grouping and safe blood transfusion among the population.

The sample size is only 164 . Of the respondents, $105(64.0 \%)$ were male and 59 $(36.0 \%)$. The frequency of group O+ve comprised the highest $(32.9 \%)$ of the samples followed by group $A+v e, B+v e$ and $A B+v e$. The majority of the subjects were Rh-D positive (94.5\%). It is observed that Rh-D positive group is more common in subjects with $O$ group whereas $R h-D$ negative group is more common in B group. The result would be more accurate if the sample number would be more.

In the present study using Bangladeshi population, the $\mathrm{ABO}$ group distribution, $\mathrm{O}$ (34.1\%), A (26.2\%), B (25.6\% and AB $(14.0 \%)$ was different from that reported distribution for different population other than Bangladeshi, O (47\%), A (41\%), B (9\%) and $\mathrm{AB}(3 \%) .{ }^{9}$ in a study showed that among the common people of Dhaka city, blood group B was the commonest followed by $O$. The distribution pattern of $\mathrm{A}, \mathrm{B}, \mathrm{O}$ and $\mathrm{AB}$ were $23.5 \%, \quad 39.8 \%, \quad 27.6 \%$ and $9.2 \%$, respectively. ${ }^{11}$ The study regarding the distribution of $A B O$ and $R$ h-D blood group systems among the people of central part of
Bangladesh was first done in 1975 by Rahman, ${ }^{11}$ where blood group $B$ was found most predominant among the population. This study showed the frequency of $\mathrm{B}, \mathrm{O}, \mathrm{A}$ and $A B$ groups were as $35.2 \%, 34.0 \%$, $22.4 \%$ and $8.4 \%$, respectively. ${ }^{11}$ Another study conducted in the rural and urban areas of Bangladesh showed the similar results of predominant blood group, B (35.5\%) followed by blood group $\mathrm{O}(32.6 \%) .{ }^{7}$ These findings are almost similar to that of common people in the current study. However, study in South East and Western part of Bangladesh demonstrated the most frequent blood group was $0 .{ }^{12,13}$ A study in Northern district of Dinajpur also indicated the group $O$ predominance with a frequency of $40.6 \%$ followed by group A $26.6 \%$, group B $23.2 \%$ and group $A B$ 9.6\%. ${ }^{7}$

Frequency of Rh-D positive among the Caucassian, Blacks and Asian were $85 \%$, $92 \%$ and $99 \%$, respectively. ${ }^{14}$ The prevalence of $\mathrm{Rh}-\mathrm{D}$ positive remains very high compared to the Rh-D negative group throughout the world. The result of this study also follows the global trend of much higher $\mathrm{Rh}-\mathrm{D}$ positive than $\mathrm{Rh}-\mathrm{D}$ negative.

\section{Conclusion}

This study showed higher frequency of O+ve group followed by by group A+ve, B+ve and $A B+v e$ which is a bit different from other study conducted among village people in Bangladesh that revealed higher frequency of $\mathrm{B}+\mathrm{ve}$ group. Rh blood group system is also similar to other previous studies. O+ve which can safely be transfused to any other group and tis can generate a local database and create social awareness about self-blood grouping and safe blood transfusion among the population.

\section{References}

1. Mourant AE. Blood group introduction. $\mathrm{Br}$ Med Bull 1959;15(2):89-91.

2. Firkin F, Chesterman $C$, Penington D, Rush B. Blood groups; blood transfusion; acquired immune deficiency syndrome. In: de Gruchy's clinical hematology in medical practice. $5^{\text {th }}$ ed. New Delhi, 
Oxford University Press; 1989:475-96.

3. Molison PL. Blood transfusion in clinical medicine. 6th ed. Oxford UK: Blackwell Scientific Publication, 1979.

4. Harmening MD, Firestone D. The ABO blood group system. In: Harmening MN, editor. Modern Blood Banking and Transfusion Practices. 5th ed. USA: FA Davis Company, Philadelphia, USA; 2005:108-32.

5. Guyton CA. Text Book of Medical Physiology. WB Saunders Company Harcourt Brace Lovauovich, Inc, 1991.

6. Mal HS. The distribution of $A B O$ and Rh-D Blood groups in local residents of Ahmedabad. IJSR- International Journal of Scientific Research 2013;2(9):1.

7. Pathan AH, Apu AS, Jamaluddin ATM, et al. Prevalence of ABO blood groups and $\mathrm{Rh}$ factor in Bangladesh. Bangladesh $\mathrm{J}$ Life Sci 2008;20(2):131-5.

8. Molison PL. Blood groups antibodies and red cell destruction. BMJ 1959; 15:1035-41.
9. Hall JE. Guyton and Hall Textbook of Medical Physiology. In: Blood transfusion; Tissue and organ transplantation, 12th ed. Saunders an imprint of Elsevice Inc. Philadilphia, USA, 2011;445-50.

10. Sultana R, Rahman Z, Helali AM, et al. Study of $A B O$ and Rh-D blood groups among the common people of capital city of Bangladesh. Int $\mathrm{J}$ Pharm Pharm Sci 2013;5(3):814-6.

11. Rahman M. Incidence of important blood groups in Bangladesh. Bangladesh Med Res Counc Bull 1975;1(1):60-63.

12. Majumder PP, Roy J. Distribution of $A B O$ Blood groups on the Indian subcontinent: a cluster-analytic approach. Current anthropol 1982;23(5):539-66.

13. Pramanik T, Adhikari P. Trend of blood group distribution among the different ethnic groups of Katmandu Valley. Nepal Med Coll J 2006;8(4):248-49.

14. Bethesda DL. Blood Groups and Red Cell Antigens. In: The Rh blood group. USA: National Center for Biochemistry Information, 2005;1-6.

\section{Suggestion for citation of the above:}

Hira RM, Dhali LK, Dhali ND, Akash DH. ABO and Rh-D blood group distribution in a rural population of Bangladesh. Mediscope 2015;2(1):22-6. 